Chen (Zhao \& Chen 2013) demonstrate that reinforced concrete and reinforcement increase in resistance when subjected to blast, due the dynamic increase factor as presented by Li et al. (Li et al. 2016). Additionally, the construction of physical barriers is one of the techniques against blast effect to protect people and buildings (Department of Defense 2008). Coatings to mitigate blast effects in structures for reducing damages are studied, these materials generally presents higher yield than RC and can absorb part of the energy of blast wave (Shim et al. 2013, Wu \& Sheikh 2013).

There are many definitions of explosion in the literature (Akhavan 2004, Keller et al. 2014, Ngo et al. 2007), but what is common for all definitions is the sudden, quick and high scale release of energy, generated due to physical, chemical or nuclear reaction. Especially for chemical explosion, the sudden elevation of temperature and pressure surrounding the epicenter of an exothermic oxidation reaction is the classical definition. This reaction occurs very fast (Sabatini et al. 2016).

Chemical explosives are substances capable of producing fast reactions enough to generate very high pressure, temperature and blast wave self-sustaining. These explosives can be classified as high or low explosives (Kubota 2007) depending on the energy of activation they need. High explosives need higher energy of activation, which can be given by a low explosive that needs few amount of energy to start its burn.

Depending on the distance of the epicenter and the construction different kind of damage can be determined for the same weight of explosive (ASCE 2010, UNODA 2011). Also, for this verification, the standardization of the explosive is needed considering the scaled distance (Z). Scaled distance is the value of stand-off distance $(R)$ in meters, over the cubic root of the mass in $\mathrm{kg}$ of equivalent TNT(W) (Brode 1955), as shown in Equation 1.

$Z=\frac{R}{\sqrt[s]{W}}$

This paper presents qualitative results of ten slab responses with different RC strength and reinforcement ratio, subjected to different scaled distance by chemical plastic bonded explosive in full-scale field tests. Three of the ten slabs were retrofitted with $50 \mathrm{~mm}$ thick expanded polystyrene foam (EPS) to verify if this material may change the structure behavior against blast. Mendonça et al. (2020) presented characterization results of this EPS foam. Researches have been done to verify the capacity of different materials and foam to influence structures response (Elshenawy et al. 2019, Sandhu et al. 2019). Results of simulation demonstrate that $5 \mathrm{~cm}$ thick foam can mitigate the blast load, transferring through the layer part of the blast energy (Elshenawy et al. 2019). Rubber foam and synthetic foam were able to mitigate acceleration of blast wave in field tests, as pointed by Sandhu et al. (2019), increasing of foam thickness generate more reduction of acceleration peak as well. The higher efficiency to reduce peak of acceleration was verified using rubber foam.

\section{Blast effect}

Detonation of high explosives can generate around $7000^{\circ} \mathrm{C}$ in the epicenter and decrease quickly, losing energy to the environment. In addition, pressure waves around 300.000 bar can be generated and moves from the epicenter compressing the surrounding air and propagating the blast wave toward the objects close to the explosion. This blast wave have supersonic velocity (Anandavalli et al. 2012, Dharma Rao et al. 2015, Ngo et al. 2007) and high capacity to produce damages to buildings, 
assets and people. Blast wave parameters have being studied well, and a typical pressure timehistory is presented in Figure 1 (ASCE 2010, Goel et al. 2012, Mendonça \& Urgessa 2017). Where $t_{A}$ is the time of arrival of blast wave front, $t_{0}$ is the positive phase of the pressure, known as time of duration of positive phase, and $t_{0}$ the negative phase (a lower pressure than the ambient pressure). The highest value measured in the first peak of the graphic in Figure 1 is the peak overpressure (Pso). There are empirical equations available in literature for predicting Pso (Chiquito et al. 2019, Kingery \& Bulmash 1984, Ngo et al. 2007).

To predict effects against structures the equations developed by Kingery and Bulmash have been widely used (Kingery \& Bulmash 1984) to predict Pso, $t_{A}$ and $t_{0}$. Integration of the positive phase of the curve gives the positive specific impulse (I), which is the main factor to generate damages in structures under blast (UNODA 2011). Equation 2 gives the expression to find positive specific impulse (ASCE 2010, Kinney \& Graham 1985). Where $t_{o i}$ is the time of beginning of the positive phase and $t_{\text {of }}$ the final time for positive phase.

$I=\int_{t o i}^{t o f} P d t$

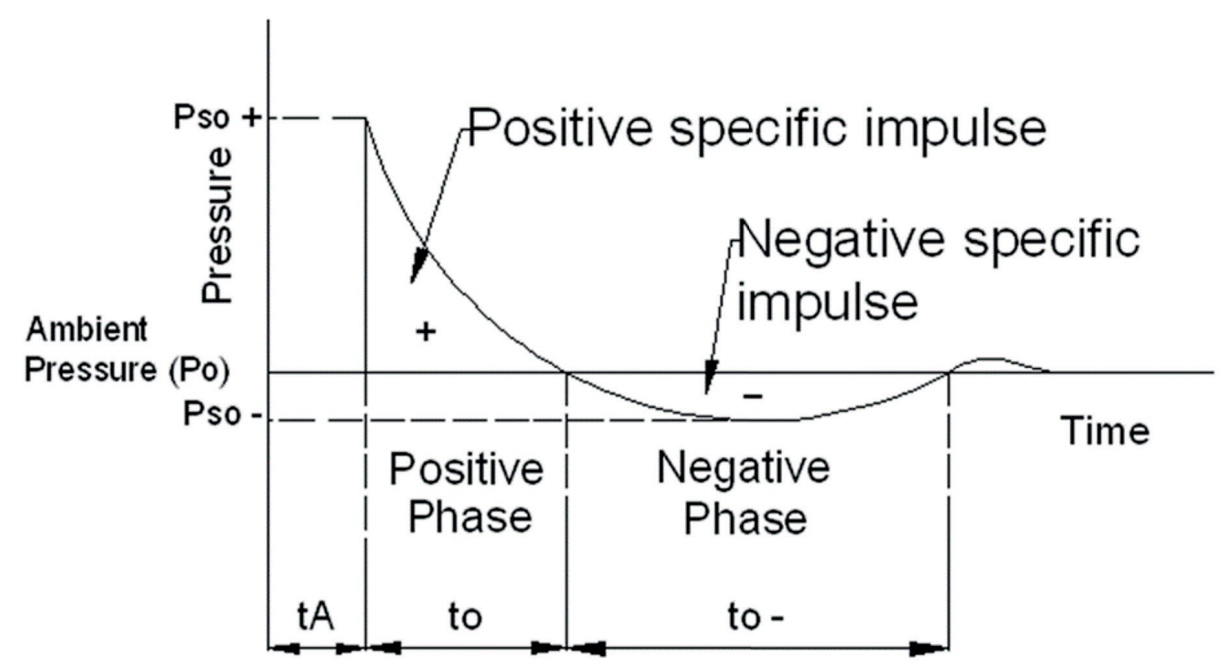

\section{MATERIALS AND METHODS}

Ten slabs measuring $1.0 \times 1.0 \times 0.08 \mathrm{~m}$ were made from 40, 50 and $60 \mathrm{MPa}$ concrete and different reinforcement ratio. The slabs were simply supported in two sides and the explosive was suspended above the slab. Due to this, the reinforcement was placed in the bottom face of the slab to support positive moment. Tensile strength for the reinforcement was estimated as $350 \mathrm{MPa}$. Table I gives the details of the slab and the explosive for the set-up of the ten tests. Reinforcement of the slabs have different ratio in each direction in four slabs. Stand-off distance was the same for eight tests, just for test 1 and test 10 they were changed. Concrete compressive strength (fck) was tested as Brazilian Standardization Norm and gave the results presented in Table I. Tensile strength for the concrete was estimated as 10 per cent of compressive strength. Figure $2 a$ presents the setup for the tests (Mendonça et al. 2017). Supports for the slabs were made from wood and have the dimensions shown in Figure $2 b$.

The explosive was non-confined due to the needs to have more reliable results without fragments influence (Mendonça et al. 2018), but just the blast wave. It was cylindrical in shape, have dimensions of $20 \mathrm{~cm}$ high and $10.5 \mathrm{~cm}$
Figure 1. Typical pressure timehistory for chemical explosion in free air. 
Table I. RC slabs and explosive information. Slabs with (*) have $5.0 \mathrm{~cm}$ thick foam retrofit (Mendonça et al. 2017).

\begin{tabular}{|c|c|c|c|c|c|c|c|c|c|}
\hline Slab & $\begin{array}{c}\text { Fck } \\
(\mathrm{MPa})\end{array}$ & $\begin{array}{l}\text { Age } \\
\text { (days) }\end{array}$ & $\begin{array}{l}\text { Bar } \\
\text { Diam. } \\
(\mathrm{mm})\end{array}$ & $\begin{array}{l}\text { Rebar } \\
\text { Spacing } \\
\text { (cm) }\end{array}$ & $\begin{array}{l}\text { Rebar } \\
\text { Direct. }\end{array}$ & $\begin{array}{c}\text { Reinforc. } \\
\text { Ratio }\end{array}$ & $\begin{array}{c}\text { TNT } \\
\text { Mass } \\
\text { (kg) }\end{array}$ & $\begin{array}{l}\text { Stand-off } \\
\text { Dist. } \\
\text { (m) }\end{array}$ & $\begin{array}{c}Z \\
\left(\mathrm{~m} / \mathrm{kg}^{1 / 3}\right)\end{array}$ \\
\hline 1 & 40 & 28 & 5 & 15 & Two way & $0.17 \%$ & 2.76 & 1.3 & 0.93 \\
\hline \multirow{2}{*}{2} & \multirow{2}{*}{50} & \multirow{2}{*}{28} & 5 & 15 & Two way & $0.17 \%$ & \multirow{2}{*}{2.72} & \multirow{2}{*}{2} & \multirow{2}{*}{1.43} \\
\hline & & & 10 & 10 & One way & $0.37 \%$ & & & \\
\hline \multirow{2}{*}{$3^{*}$} & \multirow{2}{*}{50} & \multirow{2}{*}{28} & 5 & 15 & Two way & $0.17 \%$ & \multirow{2}{*}{2.71} & \multirow{2}{*}{2} & \multirow{2}{*}{1.43} \\
\hline & & & 10 & 10 & One way & $0.37 \%$ & & & \\
\hline 4 & 60 & 28 & 5 & 10 & Two way & $0.25 \%$ & 2.69 & 2 & 1.44 \\
\hline \multirow{2}{*}{5} & \multirow{2}{*}{50} & \multirow{2}{*}{28} & 5 & 15 & Two way & $0.17 \%$ & \multirow{2}{*}{2.58} & \multirow{2}{*}{2} & \multirow{2}{*}{1.46} \\
\hline & & & 10 & 10 & One way & $0.37 \%$ & & & \\
\hline \multirow{2}{*}{$6^{*}$} & \multirow{2}{*}{50} & \multirow{2}{*}{28} & 5 & 15 & Two way & $0.17 \%$ & \multirow{2}{*}{2.72} & \multirow{2}{*}{2} & \multirow{2}{*}{1.43} \\
\hline & & & 10 & 10 & One way & $0.37 \%$ & & & \\
\hline 7 & 60 & 28 & 5 & 10 & Two way & $0.25 \%$ & 2.60 & 2 & 1.45 \\
\hline $8^{*}$ & 60 & 28 & 5 & 10 & Two way & $0.25 \%$ & 2.76 & 2 & 1.42 \\
\hline 9 & 60 & 28 & 5 & 10 & Two way & $0.25 \%$ & 2.72 & 2 & 1.43 \\
\hline 10 & 40 & 28 & 5 & 15 & Two way & $0.17 \%$ & 2.60 & 1.6 & 1.16 \\
\hline
\end{tabular}

width, and the weight information can be found in Table I. In addition, the scaled distance is presented in Table I. The explosive was triggered by electrical fuse mounted on top completing an explosive train.

Multiple reflected pressure can be generated in explosions near structures as verified in this test (Li et al. 2016, Maji et al. 2008). Integration of positive phase of the time-history pressure curve is the main factor that causes damages in structures. Reflections can increase the integration result and increase the damages. Figure 3 shows a typical time-history pressure curve with some reflections that increase the area under the curve (Mendonça 2017).

\section{Abbreviations}

EPS - Expanded Polystyrene

fck - Concrete Strength

I - Specific Positive Impulse

L - Light Damage
M - Moderate Damage

Pso - Peak overpressure

$\mathrm{R}$ - Stand-off Distance

RC - Reinforced Concrete

RR - Reinforcement Ratio

$S$ - Severe Damage

$\mathrm{t}_{\mathrm{A}}$ - Time of Arrival

$\mathrm{t}_{\text {of }}$ - Final Time of Positive Phase

$t_{o i}$ - Time of Beginning of Positive Phase

$t_{0}$ - Time of Positive Phase Duration

$t_{0-}$ - Time of Negative Phase Duration

W - Equivalent TNT Explosive Weight

Z - Scaled Distance

\section{RESULTS AND DISCUSSION}

As expected, slabs with lower stand-off distance presented higher damages and collapsed during the explosion. Slabs with lower reinforcement ratio and lower concrete strength resulted in rupture of concrete. Slabs with reinforcement 


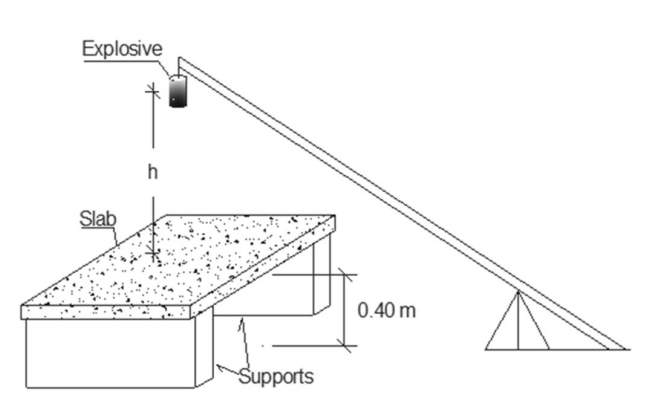

(a)

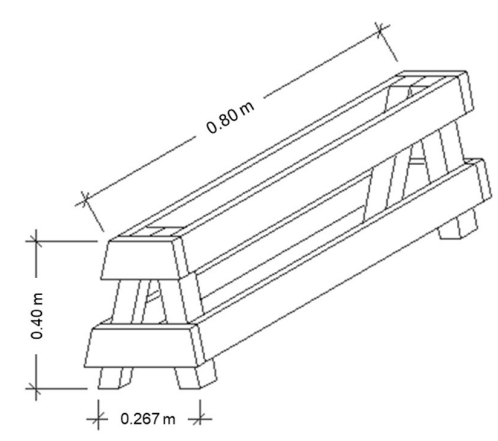

(b)
Figure 2. (a) Set-up for the test. $h$ value can be seen in Table I as standoff distance. (b) Detail of wood supports.

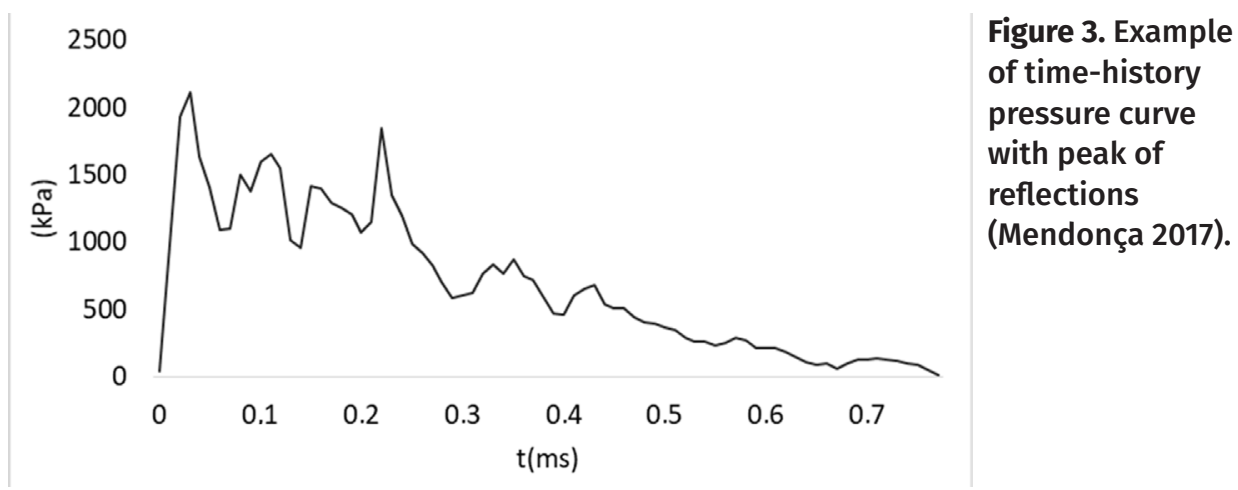

ratio higher than $0.25 \%$ could support blast effect without collapse. All these cases had concrete with 50 or $60 \mathrm{MPa}$. Concrete with 40 MPa had the lower reinforcement ratio, and was destroyed during the explosion. The position of the explosive drive the main energy of the explosion to the center of the slabs, as can be seen in Figure $4 \mathrm{a}$. The shape of explosion was the same for all tests due to the cylindrical shape of the explosive and the trigger position (Mendonça et al. 2018). Figure $4 b$ presents slab 1 after test. As can be seen in Table I, it had the lower stand-off distance, reinforcement ratio in both directions and concrete strength (40 MPa). Additionally, the scaled distance is lower than 1 $\mathrm{m} / \mathrm{kg}^{1 / 3}$. The slab collapsed completely.

Slabs with two reinforcement ratios had collapse just in direction with lower reinforcement ratio. As can be seen in Figure $4 \mathrm{c}$, slab 5 had a main crack across the section with lower reinforcement ratio $(0.175 \%)$, in other direction with $0.37 \%$ there was fewer and smaller cracks. Slab 5 had $50 \mathrm{MPa}$ of concrete strength, higher value than slab 1 shown in Figure $4 \mathrm{~b}$. However, its scaled distance was higher.

Slab 2 had a similar result as shown in slab 5. These slabs had the same configuration test. Different results pointed for many configurations of test were displayed in a damage diagram to help structural designers to verify the effects of reinforcement or concrete strength on blast response. Figure 5 presents a damage diagram showing the results for all experiments. Simply supported in two sides slabs and having reinforcement just in the bottom face, allowed to identify the slab behavior. The following steps are necessary to read the diagram:

1) Choose the combination of scaled distance (Z) and equivalent TNT explosive weight (W) values in the center of the diagram;

2) Select concrete strength (fck);

3) Choose or verify the available reinforcement ratio (RR); 


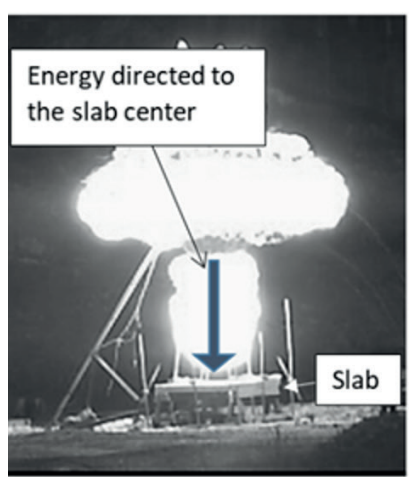

(a)

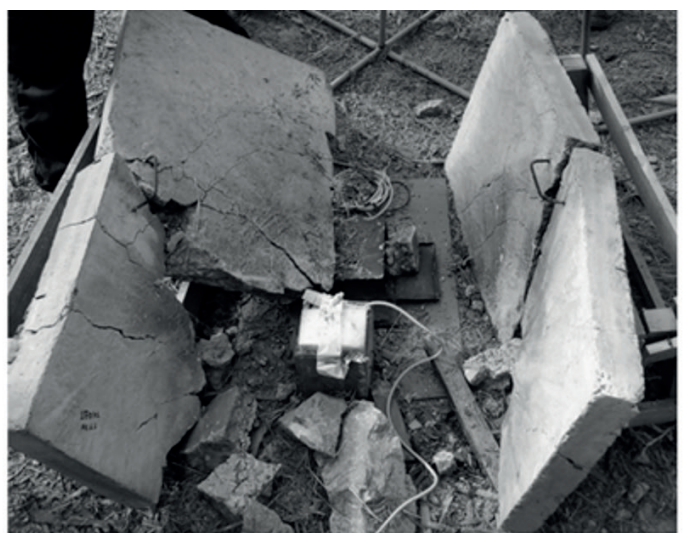

(b)

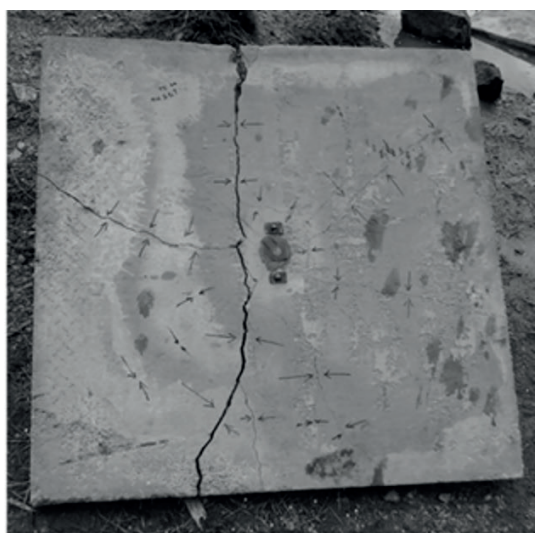

(c)

Figure 4. (a) Concentration of energy. (b) Collapse of slab 1 after test. (c) Main crack across weakness section after slab 5 test.

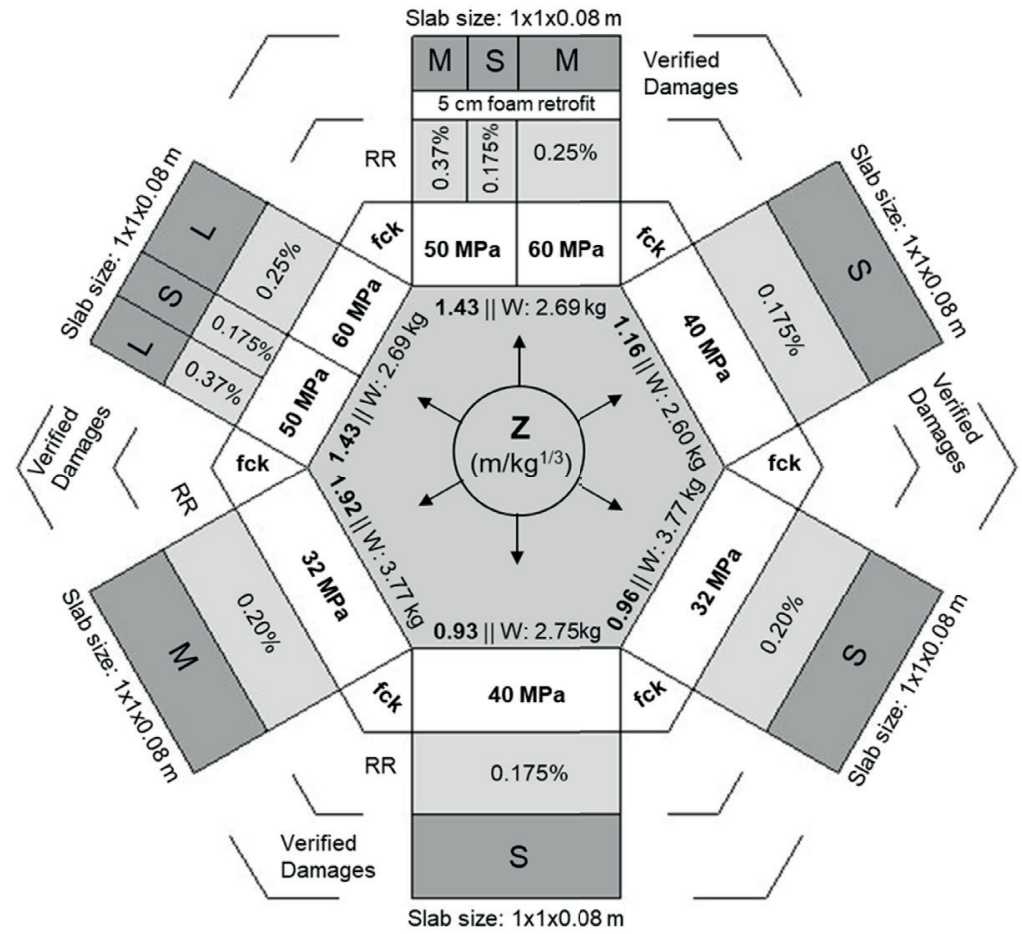

Figure 5. Damage

diagram for full-scale

field test of reinforced

concrete slabs

supported in two sides

and reinforced in the

bottom face.

4) Read the damage classification as Severe (S), Moderate (M) or Light (L) and verify if there is $5 \mathrm{~cm}$ foam retrofitted for the chosen configuration.

Damage classification was adopted according to the damage verified in qualitative analysis and follows these criteria: $\mathbf{S}$ - represents failure of the fully concrete cross section; $M$ represents generalized cracks in preferred direction without failure of reinforcement or concrete and $\mathrm{L}$ - represents minor visible cracks in only one side of the structure. Slab size is the last information given and can be expanded if future blast tests results are to be obtained.

In general, slabs with higher concrete strength and reinforcement ratio could support the blast effect better. These slabs will have light damages compared to others. Displacement 
sensors having accurate within plus or minus $0.001 \mathrm{~mm}$ were able to ensure the verification of different slabs behavior. The structures with fewer reinforcement ratio and lower concrete strength had severe damages; their response mostly leading to collapse. Lower values of scaled distance provide higher damages.

\section{CONCLUSIONS}

A damage diagram from ten full-scale field tests using non confined plastic explosive was presented. The slabs had different reinforcement ratio, concrete strength and three different scaled distance. The damage characteristics of the slabs were determined using qualitative analysis. The classification of the damages was presented in a diagram where all the results could be visualized. This diagram is a useful tool to help designers in determining probable damages that structures with similar configuration could potentially experience. The diagram can be used for many explosive scenarios as long as the scaled distance values $(Z)$ is used. Further works can be developed using different scaled distance and increasing the reinforcement ratio. The use of different thick foam and quality can be done to verify foam capacity to protect the structure.

\section{REFERENCES}

AKHAVAN J. 2004. The Chemistry of Explosives. Rs.C (Ed.), $2^{\text {nd }}$ Ed., Cambridge: RS.C.

ANANDAVALLI N, LAKSHMANAN N, IYER N, PRAKASH A, RAMANJANEYULU K, RAJASANKAR J \& RAJAGOPAL C. 2012. Behaviour of a Blast Loaded Laced Reinforced Concrete Structure. Def Sci J 62(5): 284-289.

ASCE. 2010. Design of blast-resistant buildings in petrochemical facilities. W. L. Bounds (Ed), $2^{\text {nd }}$ Ed., Reston: ASCE, 300 p.
BRODE HL. 1955. Numerical solutions of spherical blast waves. J Appl Phys 26(6): 766-775.

CHIQUITO M, CASTEDO R, LÓPEZ LM, SANTOS AP, MANCILLA JM \& YENES JI. 2019. Blast Wave Characteristics and TNT Equivalent of Improvised Explosive Device at Smallscaled Distances. Def Sci J 69(4): 328-335.

DEPARTMENT OF DEFENSE. 2008. UFC 3-340-02. Structures to resist the effects of accidental explosions, USA.

DHARMA RAO V, SRINIVAS KUMAR A, VENKATESWARA RAO K \& KRISHNA PRASAD VSR. 2015. Theoretical and Experimental Studies on Blast Wave Propagation in Air. Propellants Explos Pyrotech 1(40): 138-143.

DUSENBERRY DO. 2010. Handbook for blast-resistant design of buildings. D. Dusenberry, Ed. $1^{\text {st }}$ Ed., New Jersey: J Wiley \& Sons.

ELSHENAWYT, SEOUD MA \& ABDO GM. 2019. Ballistic Protection of Military Shelters from Mortar Fragmentation and Blast Effects using a Multi-layer Structure. Def Sci J 69(6): 538-544.

GOEL MD, MATSAGAR VA, GUPTA AK \& MARBURG S. 2012. An abridged review of blast wave parameters. Def Sci J 62(5): 300-306.

KELLER J, GRESHO M, HARRIS A \& TCHOUVELEV A. 2014. What is an explosion? Int J Hydrog Energy 39(5): 1-8.

KINGERY CN \& BULMASH G. 1984. Airblast Parameters From TNT Spherical Air Bursts and Hemispherical Surface Bursts. Maryland.

KINNEY GF \& GRAHAM KJ. 1985. Explosive shocks in air, $2^{\text {nd }}$. ed., New York: Springer Science.

KUBOTA N. 2007. Propellants and Explosives Thermochemical Aspects of Combustion. Propellants and Explosives, $2^{\text {nd }}$ Ed., Weinheim: WILEY-VCH.

LI J, WU C, HAO H, WANG Z \& SU Y. 2016. Experimental investigation of ultra-high performance concrete slabs under contact explosions. Int J Impact Eng 93: 62-75.

MACGREGOR JG \& WIGHT JK. 2005. The design process. In Greg Dulles (Ed.), Reinforced Concrete Mechanics and Design, $4^{\text {th }}$ Ed., New Jersey: Pearson, p. 33.

MAII AK, BROWN JP \& URGESSA GS. 2008. Full-Scale Testing and Analysis for Blast-Resistant Design. J Aerosp Eng 21(4): 217-225.

MAYS G, FELTHAM I \& BANFI M. 2012. Design of elements in structural steel. In D Cormie, G Mays \& P Smith (Eds)., Blast Effects on Buildings, $2^{\text {nd }}$ Ed., London: ICE, p. 103-118. MENDONÇA FB \& URGESSA GS. 2017. Pre-Test and Analysis of a Reinforced Concrete Slab Subjected to Blast from a 
Non-Confined Explosive. In RFB Gonçalves, JAFF Rocco \& K Iha (Eds.), Energetic Materials Research, Applications and New Technologies, $1^{\text {st }}$ Ed., Hershey, US: IGI Global, p. 272-287.

MENDONÇA FB, URGESSA GS, DUTRA RL, BOSCHI RF, IHA K \& ROCCO JAFF. 2020. EPS foam blast attenuation in full-scale field test of reinforced concrete slabs. Acta Sci Civ Eng 42: 1-7.

MENDONÇA FB, URGESSA G, IHA K, ROCHA RJ \& ROCCO JAFF. 2018. Comparison of Predicted and Experimental Behaviour of RC Slabs Subjected to Blast using SDOF Analysis. Def Sci J 68(2): 138-143.

MENDONÇA FB, URGESSA GS \& ROCCO JAFF. 2017. Blast Response of 60 MPa Reinforced Concrete Slabs Subjected to Non-Confined Plastic Explosives. In Proceedings of Structures Congress 2017 - ASCE (pp. 15-26). Denver, CO, US.

NGO T, MENDIS P, GUPTA A \& RAMSAY J. 2007. Blast loading and blast effects on structures - An overview. Electron J Struct Eng 7: 76-91.

SABATINI JJ, WINGARD LA, GUZMAN PE, JOHNSON EC \& DRAKE GW. 2016. Bis-Isoxazole dinitrate: A potential propellant and explosive ingredient. In Proceedings of the $42^{\text {nd }}$ International Pyrotechnics Society Seminar (p. 98-101). Grand Junction: IPSUSA Seminars.

SANDHU IS, THANGADURAI M, ALEGAONKAR PS \& SAROHA DR. 2019. Mitigation of Blast Induced Acceleration using Open Cell Natural Rubber and Synthetic Foam. Def Sci J 69(1): 53-57.

SHIM C, SHIN D \& YUN N. 2013. Pressure-impulse diagram of Multi-layered aluminium foam panels. J Eng Sci Technol 8(3): 284-295.

UNODA. 2011. International Ammunition Technical Guideline (United Nations SaferGuard), $2^{\text {nd }}$ Ed., New York.

WU C \& SHEIKH H. 2013. A finite element modelling to investigate the mitigation of blast effects on reinforced concrete panel using foam cladding. Int J Impact Eng 55: 24-33.

ZHAO CF \& CHEN JY. 2013. Damage mechanism and mode of square reinforced concrete slab subjected to blast loading. Theor Appl Fract Mech 63-64: 54-62.

\section{How to cite}

MENDONÇA FB, URGESSA GS, ALMEIDA LEN \& ROCCO JAFF. 2021. Damage diagram of blast test results for determining reinforced concrete slab response for varying scaled distance, concrete strength and reinforcement ratio. An Acad Bras Cienc 93: e20200511. DOI 10.1590/00013765202120200511.
Manuscript received on April 4, 2020;

accepted for publication on June 11, 2020

\section{FAUSTO B. MENDONÇA ${ }^{1}$}

https://orcid.org/0000-0003-2833-7249

\section{GIRUM S. URGESSA}

https://orcid.org/0000-0003-4843-9349

\section{LUIZ E.N. ALMEIDA ${ }^{3}$}

https://orcid.org/0000-0002-0850-8912

\section{JOSÉ A.F.F. ROCCO}

https://orcid.org/0000-0002-6004-6997

${ }^{1}$ Divisão de Pesquisa e Desenvolvimento, Instituto de Aplicações Operacionais, Pça. Mal. Eduardo Gomes, 50, 12228-970 São José dos Campos, SP, Brazil

${ }^{2}$ Sid and Reva Dewberry Department of Civil, Environmental, and Infrastructure Engineering, George Mason University, 4400 University Drive, MS 6C1, 22030 Fairfax, VA, USA

${ }^{3}$ Avibras Indústria Aeroespacial S.A, Rodovia dos Tamoios, km 14, Estrada do Viradouro, 1200, Viradouro, 12315-020 Jacareí, SP, Brazil

${ }^{4}$ Divisão de Ciências Fundamentais, Departamento de Química, Instituto Tecnológico de Aeronáutica, Pça. Mal. Eduardo Gomes, 50, São José dos Campos 12228-900, SP, Brazil

Correspondence to: Fausto Batista Mendonça

E-mail:faustobm@hotmail.com

\section{Author contributions}

Dr. Fausto Batista Mendonça: His contribution to the current study include setup preparation, field test and full paper preparation. Dr. Girum Solomon Urgessa: He has contributed in the methodology used for field test and review of results. Dr. Luiz Eduardo Nunes de Almeida: He has contributed in the conceptualization of the damage diagram and analysis of field test results. Dr. José Atilio Fritz Fidel Rocco: His contribution include supervision in the field test and conclusion through results.

\section{(cc) BY}

